\title{
THE MORPHO-PHONEMIC PROCESSES IN INDONESIAN ADVERTISEMENT'S SLOGANS
}

\author{
${ }^{1}$ Octavia Chandra Dewi*, ${ }^{1}$ Lia Maulia Indrayani, ${ }^{1}$ Ypsi Soeria Soemantri \\ ${ }^{1}$ English Linguistic Department, Universitas Padjadjaran, Indonesia \\ *Corresponding Author: octavia19001@mail.unpad.ac.id
}

\begin{abstract}
The use of slogans in the advertisements to introduce and to attract public's attention upon the products advertised are essential. The use of morpho-phonemic forms as the morphological process in the Indonesian advertisements' slogans nowadays are interesting to be analyzed since there are lots of them use unique forms to attract public's attention upon the product. The public's attention upon the advertisements would influence the level of public's awareness upon the product and eventually would raise the number of purchase and the usage of the product offered. This research explained the forms of the morphological process used in the Indonesian advertisement's slogans, and the purposes of the morphological process used in the Indonesian advertisement's slogans. Based on O'Grady and Dobrovolsky's theories, this research uses descriptive qualitative method by observing and documenting the forms of morpho-phonemic changing which are used in Indonesian slogans, continued by analyzing the data. The objects of the study were the texts in advertisement's slogans. The sources of the data were the Indonesian advertisement's slogans from various types of product, which were aired or published in Indonesia. The forms of the morpho-phonemic changing were studied based on morphological processes in morphology. Slogans should attract the attention from public upon the product advertised to consume or to use it. It is hope that these findings will be useful for the development of language use especially in advertising.
\end{abstract}

Keywords: Morphological Process; Morphemic; Morpho-phonemic; Phonemic; Slogan

\begin{abstract}
ABSTRAK
Penggunaan slogan dalam iklan untuk menarik perhatian khalayak dan memperkenalkan merek atas produk tertentu yang ditawarkan sangat penting. Penggunaan bentuk morfo-fonemik sebagai proses morfologi dalam slogan pada iklan-iklan di Indonesia akhir-akhir ini sangat menarik diulas, karena banyak yang menggunakan bentuk penulisan yang unik untuk menarik perhatian khalayak atas produk yang diiklankan. Perhatian publik atas iklan akan berpengaruh besar pada tingkat pemahaman publik atas produk tersebut dan pada akhirnya akan meningkatkan pula angka pembelian dan penggunaan produk yang ditawarkan. Penelitian ini menjelaskan bentuk-bentuk proses morfologi dalam proses morfemik dan fonemik yang digunakan dalam slogan iklan di Indonesia, dan tujuan penggunaan proses morfologi yang digunakan dalam slogan iklan di Indonesia. Berdasar teori O'Grady and Dobrovolsky, penelitian ini menggunakan metode deskriptif kualitatif dengan cara observasi dan dokumentasi atas bentuk-bentuk perubahan morfo-fonemik yang digunakan dalam slogan-slogan di Indonesia, dilanjutkan dengan proses analisa data. Obyek penelitian ini adalah teks dalam slogan periklanan. Sumber data yang digunakan adalah slogan-slogan periklanan di Indonesia yang mengiklankan berbagai produk, yang ditayangkan atau dipublikasikan di Indonesia. Bentukbentuk perubahan morfo-fonemik diteliti berdasarkan proses morfologi dalam studi Morfologi. Slogan sudah seharusnya menarik perhatian khalayak atas produk yang diiklankan sehingga khalayak tertarik untuk mengkonsumsi ataupun menggunakannya. Diharapkan penemuan ini akan bermanfaat bagi perkembangan penggunaan bahasa terutama di bidang periklanan.
\end{abstract}

Kata Kunci: Fonemik; Proses Morfologi; Morfemik; Morfo-fonemik; Slogan 
Dewi, O. C., Indrayani, L. M. \& Soemantri, Y. S. (2020). The Morpho-Phonemic Processes in Indonesian Advertisement's Slogans.Celtic: A Journal of Culture, English Language Teaching, Literature, \& Linguistics, 7(2), 151-162.

\section{INTRODUCTION}

Nowadays, communication is essential. Language as the mean of communication have important role to deliver the message in the communication, which can be shared to many people. The way of communication is sometimes use unique way, in spoken language (utterances) or in written language (texts). One way of communication that use texts is through advertisements.

Advertisements are used to deliver messages to public, particularly to introduce a product to public, through textual communication. According to Merriam-Webster Dictionary advertisement is short film or written notice that is shown to the public to sell a product or to make announcement. The text used in the advertisement's language which is easy to remember and is used to attract attention is slogan.

Slogans which were used in Indonesian advertisements are unique and attract the public's attention. They made the public, especially the consumers of the product, remember the messages and easily relate the slogans to the product. Slogans like, for example: "Kopiko, gantinya ngopi", or "Sampurna Hijau, asyiknya rame-rame", are easily remind the public about the products. In short, slogans can motivate their customers to support their brand, and the best slogan creation is instantly recognizable (Zuliana, Tanjung, \& Ardi, 2013).

In this research, the researchers had formulated the questions to guide the research process for an analysis. There were some questions to guide the analysis in this research in relation with the morpho-phonetics in the Indonesian advertisement's slogans, and the researchers had simplified them into two, they are: (1) to identify the forms of the morpho-phonetics in the morphological process used in the Indonesian advertisement's slogans, and (2) to find out the purposes of the morpho-phonetics in the morphological process used in the Indonesian advertisement's slogans. Though the data taken were written some in Indonesian and others in English, and need to be seen the differences between them (Napitupulu, 2016) (Nuryadi, 2019), however, the focus of the study is simply about the morpho-phonemic processes in the slogans in advertisements aired or published in Indonesia.

Based on the statement of Yule (2010), morphology is the study of word forms. The elements in the word forms are called as morphemes. Meanwhile, Booij (2005) argued that morphology is the sub discipline which deals with word forms, such as lexemes, inflections and derivations. Morphology has an impact to the development and the perception of words (Akbulut, 2017). Kridalaksana (1988) also argued similarly, that morphology is the study of morphemes and their arrangements in the word formation. Morpheme is the smallest unit of a meaning or a grammatical function (Yule, 2010). This was also stated by Plag (2002) that morphemes are minimal linguistic unit with a lexical or grammatical meaning. Morphemes only refine and give extra grammatical information to the existed meaning (Halawa, Raflis, \& Reni, 2017). This unit, could be a word or parts of words. According to O'Grady and Dobrovolsky (1997), morphological processes are changes in written English which are morphologically conditioned and involve spelling. Furthermore, morphological process deals with the word formations, or to be more specific, the forming of morphemes. Morphological processes can be said as the methods in which new words are formed (Kolanchery, 2015). Thus, it can be morphemic, or phonemic. The morpho-phonemic process is 
Celtic: A Journal of Culture, English Language Teaching, Literature and Linguistics

Vol. 7, No. 2, December 2020.

E-ISSN: 2621-9158 P-ISSN:2356-0401

http://ejournal.umm.ac.id/index.php/celtic/index

included in the morphological processes as the process of phonological realization of a morpheme (Nopriansah, 2016).

The morphemic form in morphological process is a combination of one morpheme with another morpheme to form new morpheme. In the advertisement's slogans, sometimes this formation contains the brand name of the product, which make this formation unique. This form is called unique forms (Parera, 2010). The sample form of this morphemic formation is the slogan of cigarette product A-Mild, which says "Go Ahead". Another form of the morphemic formation in morphological process is the simulfix-affixes as the result of aphaeresis. According to Kridalaksana (2008) simulfixaffixes is a type of affix that change the existing phoneme to modify the meaning of morpheme. It does not form syllable and is merged on the root word. Meanwhile, aphaeresis is the eliminating of sound or word at the beginning of the word or speech. The sample of this form is in the slogan of cigarette product U-Mild, which says "Kalo ngasih nggak pernah sedikit, meski dompet lagi pailit". The affix me- at the beginning of the word mengasih (memberi - to give) is dropped or merged into "ngasih". All of these samples of morphemic process are productive word formation process, because they can be used to produce the new words (Ratih \& Gusdian, 2018).

The phonemic form in morphological process is when a morpheme with base morpheme attached to one or several phonemes that forms a new morpheme. This is called allomorph, which means a morpheme variation that obtained from a bound morpheme that has the function as a free morpheme. This could be in the form of vowel and consonant that sounds extensively that contribute to construct words (Wardani \& Suwartono, 2019). Although the form is a little bit changed, the meaning still refers to the original form. The sample form of this phonemic formation is the slogan of another cigarette product Djarum Coklat, which says "Djarum Coklat, Nikmat Bangeeet". Another form of the phonemic formation in morphological process is the use of free variation of allophone. This form exists in the daily conversation. The sample of this form is in the slogan of cigarette product Sampurna Hijau, which says "Ga Ada Loe Ga Rame".

Though some researchers have been done before, however, most of those researches were conducted in Semantics, Semiotics, or Pragmatics studies. Only a few in small numbers analyzed similar topics in Morphology. It is interesting to know the forms of the slogans in Indonesian advertisements, and that is why this research is worth doing. Slogans are unique because they are intended to attract people's attention, that why it is an interesting topic for a research. However, the previous researches are mostly done in semantics, semiotics, or pragmatics fields of study, rarely in the field of morphology, as it has been done by Sumilat (2015) under the title of "Makna Slogan Dalam Iklan Elektronik Berbahasa Inggris Pada Majalah Berbahasa Indonesia”, and by Maulina, Widodo, and Rusminto (2018), under the title of "Penggunaan Bahasa Persuasi Iklan Komersial di Televisi dan implikasinya di SMP”. Sumilat focused the research on the meaning of the slogans, particularly in electronic advertisements. Meanwhile, Maulina focused the research on the language use of commercial advertisements on television and the impact to the junior high school students. Mustika and Hasanah (2020), Husen, Wartiningsih, and Syahrani (2018), and Putrianasari, Pradana, Anggraini, and Waljinah (2019) focused on the language style of the slogan. Mustika conducted a research entitled "Analisis Gaya Bahasa Pada Slogan Kemasan 
Dewi, O. C., Indrayani, L. M. \& Soemantri, Y. S. (2020). The Morpho-Phonemic Processes in Indonesian Advertisement's Slogans.Celtic: A Journal of Culture, English Language Teaching, Literature, \& Linguistics, 7(2), 151-162.

Makanan Produk Jepang", Husen conducted a research entitled "Analisis Gaya Bahasa Dalam Slogan Makanan Ringan Di Pontianak Kalimantan Barat", while Putrianasari conducted a research entitled "Analisis Kesalahan Gaya Bahasa pada Iklan Produk Minuman di Televisi". Viramdani and Himmawati (2017) conducted a research entitled "Morpho-Semantic Analysis in Electronic Product Brands" that focused on the morphology and semantic study upon the product brand. Meanwhile, another research which has been done in morphology was conducted by Jatnika, Suganda, Wahya, and Sobarna (2014) entitled “'Typical' Morphology System of Language Advertising of Cellular Services" which analyzed the morphological processes in the language use of cellular services' slogans.

\section{METHOD}

According to Creswell (2014), there are some steps in Qualitative Method, they are:

1. Emerging methods

2. Open ended-questions

3. Interview data, observation data, document data, and audiovisual data

4. Text and image analysis

5. Themes, patterns interpretation

Due to the explanations of Creswell, the researchers decided to use qualitative research method in this research, because it was the most suitable for the research. This research design was a descriptive qualitative method through documentation, literary, and observation analysis upon the texts used in the Indonesian advertisement's slogans.

For the techniques of data collection, the researchers referred to the techniques used by Arikunto. According to Arikunto (2013) there are four methods in collecting data, namely: 1) interview, 2) observation, 3) questionnaire, and 4) documentation. Based on the methods by Arikunto, the researchers used the documentation methods in collecting the data.

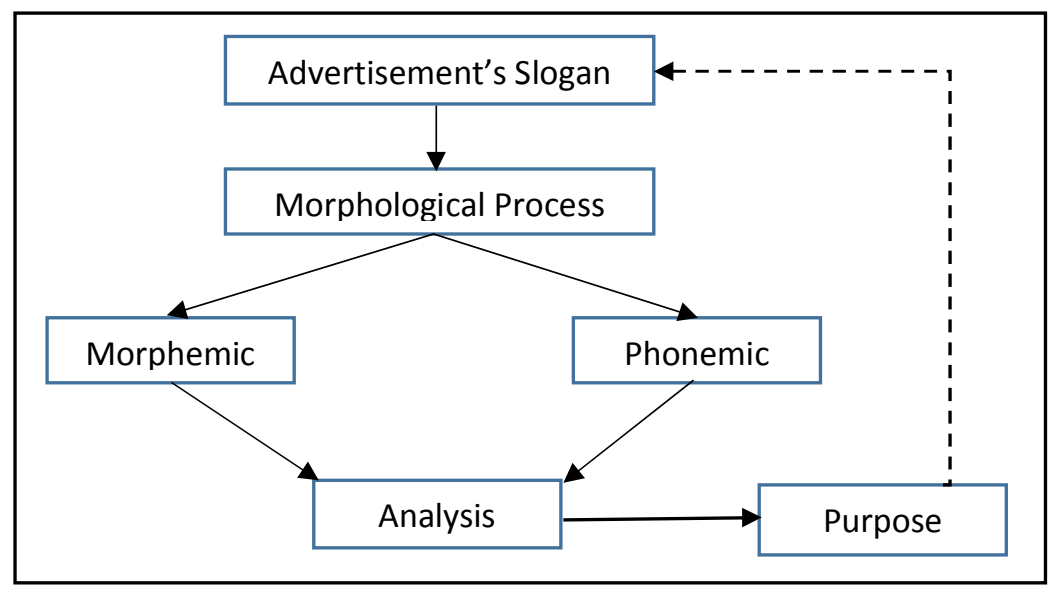

Figure 1. Theoretical Outline

The object of this research was the texts in advertisement's slogans. The source of the data analysis was the Indonesian advertisement's slogans from various types of 
product, which were aired or published in Indonesia. Those data sources were taken from internet, as it can be seen in the Table 1 below. The choosing of this object was based on the assumption that Indonesian advertisement's slogans are unique and have their own special ways in attracting the public, especially the consumers, through textual approach in morphological processes. In this research, the researchers analyzed the morphemic and phonemic upon the Indonesian advertisement's slogans through the morphological processes upon the texts based on inductive research in a structured frame of thinking.

Table 1. Data Source

\begin{tabular}{|c|c|c|}
\hline Data & Product & Slogan \\
\hline 1 & & Go Ahead \\
\hline 2 & & Masih banyak celah kok nyerah \\
\hline 3 & & Kalo gue dingin, kenapa loe yang panas \\
\hline 4 & & Taat Cuma kalo ada yang liat \\
\hline 5 & A-Mild & Other can only folL $\boldsymbol{O W}$ \\
\hline 6 & & Yang lain cuma bisa ngisep asapnya \\
\hline 7 & & Bukan BasA Basi \\
\hline 8 & & How $\boldsymbol{L} \boldsymbol{O} \boldsymbol{W}$ Can You Go? \\
\hline 9 & & Tany $\boldsymbol{A}$ Kenapa \\
\hline 10 & Sampoerna & Ga Ada Loe Ga Rame \\
\hline 11 & Hijau & Asyiknya Rame-Rame \\
\hline 12 & U-Mild & Kalo ngasih nggak pernah sedikit, meski dompet lagi pailit \\
\hline 13 & Djarum & DJARUM COKLAT, Nikmat Bangeeet \\
\hline 14 & Coklat & Yang penting Hepiii... \\
\hline 15 & LA Lights & LA LIGHTS, Enjoy $\boldsymbol{A j a}$ \\
\hline 16 & Star Mild & LOSTA MASTA (lots of mild star) \\
\hline 17 & Extreme Mild & Extremely Yours \\
\hline 18 & Kopiko & Gantinya Ngopi \\
\hline 19 & Dancow & Aku dan Kau, suka DANCOW \\
\hline 20 & McDonalds & I'm Lovin' It \\
\hline 21 & Citibank & Citi Never Sleeps \\
\hline 22 & Jaguar & Grace, Space, Pace \\
\hline
\end{tabular}

There was hypothesis that the texts used in Indonesian slogans were using unique forms from morphological process that forms different idea for the purpose of commercial use. It is understandable that these unique forms were used to attract the public, particularly the consumer targets of the product. To specify the scope of the study, the researchers chose the advertisement's slogan that contain unique forms in their texts, written in English and Indonesian. Although several of these slogans were written in English, they were used in Indonesian TV commercials. The unique forms were suspected as result of morphological processes, which have differences in morphemic forms and phonemic forms. The use of the unique forms was suspected to 
be the main cause that influence the public to pay attention more on the advertisements and remember the products deeper and longer. By analyzing the forms, the researchers tried to find the characteristics of the morphological processes which appeared in the advertisement's slogans, to find the forms of the processes, to find the function of the forms, and drew the conclusion. By the effort of the analysis, the researchers hoped that this research would be useful for the linguistics field and gave further information to the readers or the society about morphological processes that form unique slogans in advertisements which might attract the public.

\section{FINDINGS AND DISCUSSION}

The researchers had collected some Indonesian advertisement's slogans which were detected to contain morphological processes in them. There were twenty-two slogans from twelve products taken as data source, as it can be seen in the Table 1 above. Of those collected data source that contained morphological processes, some of them are detected to have the morphemic processes, phonemic processes, or both processes. The explanations of the processes can be seen as follows:

\subsection{Morphemic Formation in Morphological Processes}

Morphemic forms in morphological processes are the formation to combine one morpheme with another morpheme to form new morpheme. Kolanchery (2015) has explained in his research that this process deals with the structure of words. In his research he explained that there are various processes included in the morphological processes, in the form of morphemic formation. Some of them are including the additional of affixes, compounding, shortening, suppletion, alphabet-based formation, etc. The additional of suffix -ly is also a form of morphemic formation, as well as the process of combining two or more stems.

In this research, the data source collected have the character of morphological process in morphemic formation. The samples of these formation can also be seen in the data of the present research which are listed below:

\section{Data 1. Go Ahead}

Data 2. Masih banyak celah kok nyerah

Data 5. Other can only folLOW

Data 6. Yang lain cuma bisa ngisep asapnya

Data 7. Bukan BasA Basi

Data 8. How $\boldsymbol{L} \boldsymbol{O} \boldsymbol{W}$ Can You Go?

Data 9. Tany $\boldsymbol{A}$ Kenapa

Data 12. Kalo ngasih nggak pernah sedikit, meski dompet lagi pailit

Data 17. Extremely Yours

Data 18. Gantinya Ngopi

Data 21. Citi Never Sleeps 
Of those data included in this section of morphemic formation, there is another division based on how the words are formed. These data are divided into Unique Forms and Simulfix-affix forms. The explanations are as follows:

\subsubsection{Unique Forms in Morphemic Formation}

Unique Form is a formation of morpheme that contains special morpheme, in this case, the brand name of the product, attached to other morpheme which make this formation unique. Parera (2010) argued that a unique form is created when a form which cannot stand alone is combined only with the right partner, such as the form of sunyisenyap, lalulalang, or lenggaklenggok. In relation to this, Jatnika et al. (2014) used this theory in their research upon cellular slogans, such as the form of XLalu $(X L)$, in which the brand name of cellular service company is attached to the word selalu, and formed their slogan.

The formation of combining brand names to certain words that created unique slogan is also applied in the present research. There are data source that used the combination of the brand names and certain words in their slogans. The samples of this formation can be seen in the following data:

Data 1. Go Ahead

Data 5. Other can only folLOW

Data 7. Bukan BasA Basi

Data 8. How $\boldsymbol{L} \boldsymbol{O} \boldsymbol{W}$ Can You Go?

Data 9. Tany $\boldsymbol{A}$ Kenapa

Data 17. Extremely Yours

Data 21. Citi Never Sleeps

In the data above there are unique formations in the slogan texts, namely: Ahead, follow, basA, Low, tanyA, Extremely, and Citi. They are combinations of two morphemes which form new unique morphemes. The formation of Ahead, bas $\boldsymbol{A}$, tany $\boldsymbol{A}$, and Extremely, are combinations of the brand name with other morphemes that form words which can have meaning when they are attached in the clause or phrase. Ahead, bas $\boldsymbol{A}$, and tany $\boldsymbol{A}$, contain phoneme "A" which is a part of the product's brand "AMild". While Extremely is a combination of suffix -ly which was preceded by "extreme", a part of the brand name of cigarette product, Extreme Mild. Meanwhile, the morpheme "low" is the brand image (perception of consumers) of the product's brand of "A-Mild", which argued that they have the lowest tar and nicotine in their products. These formations in some processes are called blending, which is attaching together the beginning part of one morpheme onto the end part of another.

The slogan "Citi never sleeps" of Citibank has a little bit different case. It is a part of the brand which stand alone as independent morpheme "Citi", without changing the ending -i to -y to resemble the word "city".

These forms have the purpose to make the brand and the brand image easy to remember and unforgettable. Furthermore, it is used to refer the slogan directly to the product. 
Dewi, O. C., Indrayani, L. M. \& Soemantri, Y. S. (2020). The Morpho-Phonemic Processes in Indonesian Advertisement's Slogans.Celtic: A Journal of Culture, English Language Teaching, Literature, \& Linguistics, 7(2), 151-162.

\subsubsection{Simulfix-affix Forms in Morphemic Formation}

Simulfix-affixes is a type of affix that does not form syllable, but is merged on the root word, as a result of aphaeresis. This aphaeresis according to Kridalaksana (2008) is a process of eliminating sound or word at the beginning of the word or speech. This formation changes the form of the existing phoneme and results to the modification of the meaning of the morpheme. The examples of this formation are ngobrol created from mengobrol (chatting), and ngebut from mengebut (speeding).

Some data source found for this research are detected to adopt this formation. In the form of daily conversation language, these simulfix-affixes forms are used in the slogans for certain products. The samples of this formation can be seen in the following data:

Data 2. Masih banyak celah kok nyerah

Data 6. Yang lain cuma bisa ngisep asapnya

Data 12. Kalo ngasih nggak pernah sedikit, meski dompet lagi pailit

Data 18. Gantinya Ngopi

In the data list above, the morphemes nyerah, ngisep, ngasih, and ngopi, are simulfix forms of menyerah, mengisep (menghisap - in daily conversation language), mengasih (memberi - in daily conversation language), and mengopi (derived from "minum kopi" in daily conversation language) respectively. The prefix me- is dropped and merged into the root word. In fact, simulfiks $\mathrm{y}$ - cannot be used in the standard language, only be used in the nonformal daily conversation. These forms have the purpose to make the slogans friendlier and more familiar to the public.

\subsection{Phonemic Formation in Morphological Processes}

The phonemic form in morphological processes usually happens in the forms of allomorph. Kridalaksana (2008) stated that allomorph might be variants of morphemes that appears in another unpredictable morpheme environment, and sometimes act as free morpheme.

There are data in this research detected to have the phonemic formation. These form have the formation created from the changing of allomorph, or have unpredictable morpheme forms. The samples of these formation are listed below:

Data 3. Kalo gue dingin, kenapa loe yang panas

Data 4. Taat Cuma kalo ada yang liat

Data 10. Ga Ada Loe Ga Rame

Data 11. Asyiknya Rame-Rame

Data 13. DJARUM COKLAT, Nikmat Bangeeet

Data 14. Yang penting Hepiii...

Data 15. LA LIGHTS, Enjoy $\boldsymbol{A j a}$

Data 16. LOSTA MASTA (lots of mild star)

Data 19. Aku dan Kau, suka DANCOW

Data 20. I'm Lovin' It

Data 21. Citi Never Sleeps 
Celtic: A Journal of Culture, English Language Teaching, Literature and Linguistics

Vol. 7, No. 2, December 2020.

E-ISSN: 2621-9158 P-ISSN:2356-0401

http://ejournal.umm.ac.id/index.php/celtic/index

\section{Data 22. Grace, Space, Pace}

These data are divided into Allomorph Forms and Free Variation of Allophone forms. The explanations are as follows:

\subsubsection{Allomorph Forms in Phonemic Formation}

Allomorph means a morpheme variation that is taken from a bound morpheme which has the function as a free morpheme. According to Jatnika et al. (2014), the formation consists of a base morpheme and several phonemes, which creates a new morpheme. In their research, they gave sample words such as suweerr (swear) and sekalee (from the word sekali, means very). These forms relate with the statement given by Kridalaksana above. The samples of this formation can be seen in the following data:

Data 13. DJARUM COKLAT, Nikmat Bangeeet

Data 14. Yang penting Hepiii...

Data 15. LA LIGHTS, Enjoy Aja

Data 19. Aku dan Kau, suka DANCOW

Data 20. I'm Lovin' It

Data 21. Citi Never Sleeps

\section{Data 22. Grace, Space, Pace}

In the data above, it can be seen that there are variations of allomorph in these formations. In the data 13 and 14, the word "bangeeet" and "hepiii" have additional vowels which were attached to the base morphemes. The patterns for these forms will be morpheme banget $+v v$, and morpheme hepi $+v v$ respectively. "Banget" is a daily conversation for "very", and "hepi" is a daily conversation language for "happy". The purpose of these formations is to express something in superlative quality.

The slogan in data 15 show the form of allophone, results from the use of daily conversation. The word "aja" is derived from the word "saja", which lost its beginning part. Meanwhile, "lovin" which is ended in velar nasal sound [y] changed into alveolar nasal sound $[\mathrm{n}]$. These formations are typical of daily conversation language, to make the conversation friendlier and more familiar.

The formation of "Dan Kau", "Citi", and "Grace, Space, Pace", in data (20), (21), and (22) respectively, are word plays resulted from allomorph. "Dan Kau" in Indonesian has similar sound with "Dancow" pronounced in English, to refer the slogan to the brand product "Dancow". The word "City" has the same sound with "Citi" to remind the public about the brand product "Citibank". While the slogan "Grace, Space, Pace" has minimal pairs in the sound "ace" to form word play which has a purpose to refer to the brand product "Jaguar".

\subsubsection{Free Variation of Allophone Forms in Phonemic Formation}

Free variation of allophone usually exists in the daily conversation. These forms changed the sound according to how they are pronounced in daily language. Wardani and Suwartono (2019) gave some samples of this changing sounds in their research such 
Dewi, O. C., Indrayani, L. M. \& Soemantri, Y. S. (2020). The Morpho-Phonemic Processes in Indonesian Advertisement's Slogans.Celtic: A Journal of Culture, English Language Teaching, Literature, \& Linguistics, 7(2), 151-162.

as an addition of phoneme $/ \mathrm{n} /$ in word the as $/ \mathrm{nthe} /$, or the omission of aspirations in the word $\mathrm{pull} / \mathrm{phul} / \mathrm{as} / \mathrm{pul} /$. This changing form of pronunciation is the result of some factors, namely native language, age, motivation, etc.

Some words in the data of the present research are detected to have the characteristic mention above. The samples of this formation can be seen in the following data:

Data 3. Kalo gue dingin, kenapa loe yang panas

Data 4. Taat Cuma kalo ada yang liat

Data 10. Ga Ada Loe Ga Rame

Data 11. Asyiknya Rame-Rame

Data 16. LOSTA MASTA (lots of mild star)

The free variation of allophone is a result of the language use as daily conversation. As it can be seen in the data 3 and data 4, the words "kalo" and "liat" are the free variations from the word "kalau" (if) and "lihat" (to see), respectively. The words "rame" and "rame-rame" in data 10 and 11, are the free variations from the words "ramai" (cheerful; rousing) and "ramai-ramai" (many people acting together), respectively. Meanwhile, the slogan in data 16 has a little bit different form. "losta masta" is a result of the way people say "lots of mild star" in unique way as free variation of allophone and a word play. All of these formations have the purpose of being friendlier and more familiar with the public. Furthermore, it is to attract the public's attention and refer the slogans to the brand products.

\section{CONCLUSION}

From the analysis of the slogan texts, it can be seen that there are processes happened in the morphological processes to form unique slogans. They are morphemic and phonemic processes. The morphemic formations might result in unique forms and simulfix-affix forms. While the phonemic formations might result in allomorph forms and free variation of allophone. Based on the result of the analysis, the morphological processes are intended to

(1) Make the brand and the brand image easy to remember and unforgettable, as in: Go Ahead; How Low Can You Go?;

(2) refer the slogan directly to the product, as in: Extremely Yours; The Citi Never Sleeps;

(3) Make the slogans friendlier and more familiar to the public, as in: LA LIGHTS, Enjoy Aja; I'm Lovin' It; Ga Ada Loe Ga Rame;

(4) Express something in superlative quality, as in: DJARUM COKLAT, Nikmat Bangeeet; Yang penting Hepiii...

(5) Form word play, as in: Aku dan Kau, suka DANCOW; Grace, Space, Pace; LOSTA MASTA.

This analysis of morphological processes on the Indonesian advertisement's slogans hopefully can be useful for us to know about unique forms of Indonesian slogan and their function on commercial use, especially for those who want to know the morphemic and phonemic form on the morphological processes. 
Celtic: A Journal of Culture, English Language Teaching, Literature and Linguistics

Vol. 7, No. 2, December 2020.

E-ISSN: 2621-9158 P-ISSN:2356-0401

http://ejournal.umm.ac.id/index.php/celtic/index

Words can give powerful effect to the readers. With the unique forms that were created well, it might attract the public's attention, moreover to deliver the message better.

\section{REFERENCES}

Akbulut, F. D. (2017). Effects of morphological awareness on second language vocabulary knowledge. Journal of Language and Linguistic Studies, Vol. 13 (1), $10-26$.

Arikunto, S. (2013). Prosedur Penelitian: Suatu Pendekatan Praktek. Jakarta: PT. Rineka Cipta Press.

Booij, G. (2005). The Grammar of Words. Oxford: Oxford University Press.

Creswell, J. W. (2014). Research design: qualitative, quantitative, and mix-method approaches (4th ed.). California: Sage.

Halawa, A., Raflis, \& Reni, F. (2017). An analysis of derivational and inflectional english morphemes. Jurnal Ilmiah Langue and Parole, Vol. 1 (1), 132-144.

Husen, D. P., Wartiningsih, A., \& Syahrani, A. (2018). Analisis gaya bahasa dalam slogan makanan ringan di pontianak kalimantan barat. Jurnal Pendidikan dan Pembelajaran Khatulistiwa, Vol. 7 (9).

Jatnika, A. W., Suganda, D., Wahya, \& Sobarna, C. (2014). 'Typical ' Morphology System of Language Advertising of Cellular Services. International Journal of Linguistics Macrothink Institute, ISSN 1948-5425, 2014, Vol. 6, No. 3. doi:10.5296/ijl.v6i3.5838

Kolanchery, G. (2015). Analytical components of morphology in linguistics. Global English-Oriented Research Journal (Research English), Vol. 1 (1), 161-166. doi:10.13140/RG.2.1.5082.7609

Kridalaksana, H. (1988). Beberapa Prinsip Perpaduan Leksem dalam Bahasa Indonesia. (Disertasi), Universitas Indonesia Jakarta.

Kridalaksana, H. (2008). Kamus Linguistik. Jakarta: Gramedia.

Maulina, F., Widodo, M., \& Rusminto, N. E. (2018). Penggunaan Bahasa Persuasi Iklan Komersial di Televisi dan implikasinya di SMP. Jurnal Kata (Bahasa, Sastra, dan Pembelajarannya).

Mustika, L. D., \& Hasanah, L. U. (2020). Analisis gaya bahasa pada slogan kemasan makanan produk jepang. Mezurashii Journal, Vol. 2 (1), 55-62.

Napitupulu, F. (2016). Comparative study of compound words in English and Indonesian. The Episteme Journal of Linguistics and Literature, Vol. 3 (1).

Nopriansah. (2016). Morphophonemic process of words borrowed from English in Serawai language. Literary Cricism Journal, Vol. 3 (1).

Nuryadi. (2019). Kata dan proses pembentukan kata dalam bahasa inggris dan bahasa indonesia: suatu analisis kontrastif. Jurnal Makna, Vol. 4 (1).

O'Grady, W., \& Dobrovolsky, M. (1997). Contemporary Linguistics: An Introduction (3rd ed.). Boston, New York: Bedford/St. Martin's

Parera, J. D. (2010). Morfologi Bahasa. Jakarta: Gramedia Pustaka Utama.

Plag, I. (2002). Word-formation in English. Cambridge: Cambridge University Press.

Putrianasari, R. A., Pradana, D. A., Anggraini, D., \& Waljinah, S. (2019). Analisis kesalahan gaya bahasa pada iklan produk minuman di televisi. Paper presented at the (Proceeding) The 10th University Research Colloqium 2019: Bidang Sosial Ekonomi dan Psikologi, Gombong. 
Dewi, O. C., Indrayani, L. M. \& Soemantri, Y. S. (2020). The Morpho-Phonemic Processes in Indonesian Advertisement's Slogans.Celtic: A Journal of Culture, English Language Teaching, Literature, \& Linguistics, 7(2), 151-162.

Ratih, E., \& Gusdian, R. I. (2018). Word formation processes in english new words of oxford english dictionary (oed) online. CELTIC: A Journal of Culture, English Language Teaching, Literature \& Linguistics, Vol. 5 (No.2), 24-35. doi:10.22219/celtic.v5i2.7617

Sumilat, J. L. (2015). Makna Slogan Dalam Iklan Elektronik Berbahasa Inggris Pada Majalah Berbahasa Indonesia. Universitas Sam Ratulangi Manado., Manado.

Viramdani, I. R., \& Himmawati, D. R. (2017). Morpho-semantic analysis in electronic product brands. Language Horizon Journal, Vol. 5(01), 1-11.

Wardani, N. A., \& Suwartono, T. (2019). Javanese languageinterference in the pronunciation of english phonemes. CELTIC: A Journal of Culture, English Language Teaching, Literature \& Linguistics, Vol. 6 (No.2 ), 14-25. doi:10.22219/celtic.v6i2.8589

Yule, G. (2010). The Study Of Language 4ed. Cambridge: Cambridge University Press Textbooks.

Zuliana, N., Tanjung, F., \& Ardi, H. (2013). An analysis of language style used in the slogan of advertisement that found in the internet. ejournal Bung Hatta University, Vol.2 (2), 1-8. 